\title{
Penguatan minat literasi melalui layanan informasi pada taman baca masyarakat
}

\author{
Cindy Marisa \\ Universitas Indraprasta PGRI \\ E-mail: cindy.marisa@unindra.ac.id \\ Devi Ratnasari \\ Universitas Indraprasta PGRI
}

\begin{abstract}
Abstrak
Pemanfaatan ilmu dan pengetahuan menjadi dasar bagi individu untuk mencapai kehidupan yang efektif, dimulai dari kegiatan mempelajari hingga memaknai konten yang dipelajarinya. Pada abad ke-21, kegitan literasi harus menjadi gaya hidup bagi individu sehingga individu memperoleh kehidupan yang layak dan efektif. Indonesia menggalakkan program yang disebut Gerakan Literasi Nasional. GLN ini bergerak dari lingkungan keluarga,sekolah, dan masyarakat. TBM Irama 212 merupakan wadah masyarakat yang mendukung gerakan tersebut. Namun, dalam pelaksanaannya masih ditemui kurangnya minat literasi bagi para anggotanya. Lebih jauh, TBM yang belum lama berdiri ini, belum memiliki tata kelola yang semestinya menurut GLN. Untuk dapat membantu permasalahan tesebut, diberikan layanan informasi untuk memperkaya wawasan dan pengetahuan pengelola TBM terkait tata kelola dan strategi GLN di lingkup masyarakat. Selain itu, para anggota rumah baca diberikan layanan intensif berupa konseling kelompok yang membahas secara mendalam hambatan pada proses literasi sehingga berdampak pada peningkatan minat literasi di TBM Irama 212 tersebut.
\end{abstract}

Kata kunci: Minat Literasi; Layanan Informasi; Taman Baca Masyarakat

\begin{abstract}
The use of knowledge and knowledge becomes the basis for individuals to achieve effective lives, starting from learning activities to interpreting the content they are learning. In the 21 st century, literacy activities must become a lifestyle for individuals so that individuals get a decent and effective life. Indonesia is promoting a program called the National Literacy Movement. GLN operates from the family, school and community environment. TBM Irama 212 is a community forum that supports this movement. However, in its implementation there is still a lack of interest in literacy for its members. Furthermore, TBM, which was recently established, does not yet have proper governance according to GLN. To be able to help with these problems, information services are provided to enrich the insights and knowledge of TBM managers related to GLN governance and strategy in the community. In addition, members of the reading house are provided with intensive services in the form of group counseling that discuss in depth the obstacles to the literacy process so that it has an impact on increasing literacy interest at TBM Irama 212.
\end{abstract}

Keywords: Literacy Interest; Information Services; Community Reading Park 


\section{PENDAHULUAN}

Negara yang maju dan berkembang tentu tidak terlepas dari sumber daya manusia yang mumpuni dalam keahliannya. Kompentesi sumber daya manusia yang mumpuni dapat dicapai dengan adanya eksplorasi dan pengembangan potensi secara efektif ${ }^{1}$. Kegiatan tersebut harus dilakukan sejak dini dan terprogram secara sistematis. Hal tersebut menjadi perhatian bagi segenap bangsa, bermula dari pengasuhan, pengasihan dan pengasahan orang tua sebagai penanggung jawab dalam keluarga. Keluarga merupakan pendidik pertama yang mengarahkan dan mengembangkan individu pada potensi yang dimilikinya ${ }^{2}$. Lebih lanjut pada lembaga pendidikan yaitu sekolah. Sekolah secara terprogram dan sistematis mengasah dan mengembangkan potensi peserta didik sesuai dengan potensi yang dimilikinya. Selain itu, lingkungan masyarakat juga menjadi sarana pembelajaran bagi individu baik secara langsung maupun tidak langsung dalam mengembangkan potensi dirinya ${ }^{3}$.

Ketiga lingkungan yang mendukung dalam perkembangan individu perlu menciptakan keselarasan sehingga tercipta sumber daya manusia yang kompeten dalam mensukseskan pembangunan bangsa. Lingkungan keluarga, sekolah dan masyarakat perlu bersinergi secara sistematis sehingga tercapai tujuan yang diinginkan ${ }^{4}$. Sumber daya manusia akhirnya memiliki makna guna, daya guna dan karya guna untuk membangun bangsa. Dalam menghasilkan sebuah karya yang berguna, diawali dengan kemampuan individu memaknai konten tertentu. Pemaknaan sebuah konten berawal dari kemampuan dasar. Kemampuan dasar yang perlu diperkuat sehingga individu dapat mengembangkan ilmu dan pengetahuan, antara lain membaca, menulis dan berhitung. Lebih jauh kemampuan itu dapat mengarah pada menganalisis hingga memanfaatkan berbagai informasi yang diperlukan.

\footnotetext{
${ }^{1}$ H Saihudin, Manajemen Sumber Daya Manusia (Uwais Inspirasi Indonesia, 2019).

${ }^{2}$ Dian A Afriani, "Pelaksanaan Pendidikan Agama Islam Di Lingkungan Keluarga, Sekolah Dan

Masyarakat," Zirah 1, no. 1 (2019): 99-105.

${ }^{3}$ Bisarul Ihsan, "PERAN PEMBELAJARAN BUDAYA LOKAL DALAM PEMBENTUKAN

KARAKTER SISWA MADRASAH IBTIDAIYAH (MI)," MIDA: Jurnal Pendidikan Dasar Islam 2, no. 2 (2019): 1-8.

${ }^{4}$ Etik Kurniawati, "MANAJEMEN LEMBAGA PENDIDIKAN ISLAM DALAM MENINGKATKAN PROFESIONALISME GURU DI SMP IT DARUSSALAM SRAGEN," Jurnal PROGRESS: Wahana Kreativitas Dan Intelektualitas 7, no. 1 (2019).
} 
Namun kemampuan tersebut masih tergolong rendah di Indonesia jika dibandingkan dengan negara-negara lain di dunia. Negara Indonesia pada tahun 2018 mengalami penurunan dalam tes yang diselenggarakan oleh PISA terkait kemampuan membaca, matematika dan sains. Pada tahun 2018, Indonesia menduduki peringkat 75 dari 80 negara yang terlibat dalam kategori membaca. Berturut-turut, nilai untuk Membaca, Matematika, dan Sains dari hasil tes di 2018 adalah 371, 379, dan 396. Nilai ini mengalami penurunan dibanding tes di tahun 2015, di mana berturut-turut Membaca, Matematika, dan Sains kita meraih skor 397, 386, 403. Dari semua skor itu, Membaca memiliki penurunan skor terendah, dan bahkan di bawah skor di tahun 2012 yaitu $396^{5}$.

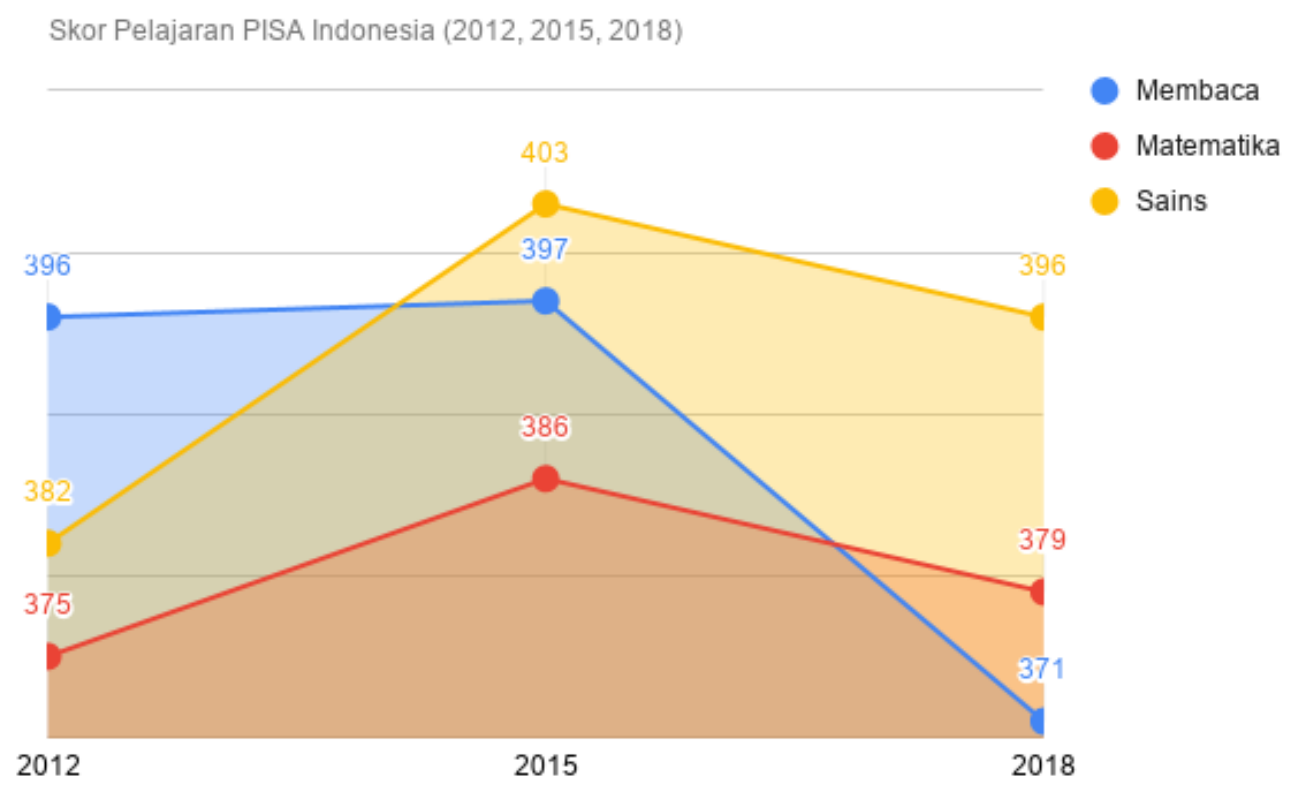

Kondisi ini tentu perlu mendapat tanggapan yang serius. Segenap lingkungan perlu memiliki sikap dan tindakan yang terarah untuk mencapai kemajuan bangsa. Pemerintah telah menggalakkan Gerakan Literasi Nasional sejak 2016 untuk menyikapi kondisi bangsa. Gerakan Literasi Nasional bertujuan menumbuhkembangkan budaya literasi pada ekosistem pendidikan mulai dari keluarga, sekolah, dan masyarakat dalam rangka pembelajaran sepanjang hayat

\footnotetext{
${ }^{5}$ Kurnia Rahmi Yuberta, "KEMAMPUAN LITERASI MATEMATIS SISWA DENGAN MENERAPKAN MODEL PEMBELAJARAN CREATIVE PROBLEM SOLVING (CPS)," Jurnal Saintika Unpam: Jurnal Sains Dan Matematika Unpam 3, no. 1 (2020): 68-80.
} 
sebagai upaya meningkatkan kualitas hidup ${ }^{6}$. Enam literasi dasar sebagai konsep dalam Gerakan Literasi Nasional, yaitu sebagai berikut ${ }^{7}$ :

1. Literasi bahasa adalah pengetahuan dan kemampuan membaca dan menulis, mengolah dan memahami informasi saat melakukan proses membaca dan menulis serta kemampuan menganalisis, menanggapi dan menggunakan bahasa.

2. Literasi numerasi adalah pengetahuan tentang dan kemampuan untuk menggunakan berbagai macam angka dan simbol-simbol yang terkait dengan angka-angka serta operasi matematika dasar (tambah, kurang, kali, bagi) serta kemampuan menggunakan makna angka dan simbol untuk menganalisis informasi dan memecahkan masalah dalam kehidupan sehari-hari.

3. Literasi sains diartikan sebagai pengetahuan tentang dasar-dasar berbagai cabang sains dan kemampuan untuk mengaplikasikan sains dasar dalam kehidupan sehari-hari dengan cara mengidentifikasi pertanyaan, menginterpretasi data dan bukti sains serta menarik kesimpulan yang berkenaan dengan alam dan pemeliharaannya.

4. Literasi digital adalah pengetahuan tentang dasar-dasar teknologi informasi dan komunikasi dan kemampuan untuk menggunakan media digital, alat-alat komunikasi atau jaringan untuk menemukan, mengevaluasi, menggunakan, membuat informasi dan memanfaatkan secara sehat, bijak, cerdas, cermat, tepat, dan patuh hukum dalam rangka membina komunikasi dan interaksi dalam kehidupan sehari-hari.

5. Literasi finansial adalah pengetahuan tentang rumusan konsep dan tujuan finansial serta praktik kewirausahaan dan kemampuan dalam mengatur untuk menghasilkan, mengelola, menginvestasikan, dan menyumbangkan uang.

6. Literasi budaya dan kewarganegaraan adalah pengetahuan tentang berbagai sejarah, kesenian, tradisi dan nilai-nilai yang terkandung di dalamnya, hak dan kewajiban warga negara Indonesia dan kemampuan mengenal, memahami, menghargai berpartisipasi secara aktif dalam budaya dan nilai-nilai kebangsaan dan kewarganegaraan, serta bertingkah laku sesuai dengan nilai-nilai budaya dan regulasi formal yang berlaku di Indonesia.

\footnotetext{
${ }^{6}$ Meidawati Suswandari, "Membangun Budaya Literasi Bagi Suplemen Pendidikan Di Indonesia," Jurnal Dikdas Bantara 1, no. 1 (2018).

${ }^{7}$ Erna Yayuk, Kuncahyono Kuncahyono, and Arina Restian, "Pendampingan Gerakan Literasi Sains (GLS) Di SDN Girimoyo 2 Malang,” Publikasi Pendidikan 8, no. 3 (2018): 172-78.
} 
TBM Irama 212 merupakan gerakan masyarakat yang peduli terhadap peningkatan minat membaca di wilayah Depok. Namun dalam pengelolaannya, belum secara penuh terintegrasi dengan gerakan literasi nasional. Pengelolaan TBM Irama 212 yang terbilang masih muda, perlu diberikan arahan agar bersinergi dengan gerakan literasi nasional yang digalakkan oleh Kememndikbud. Kondisi yang terjadi pada anggota dalam TBM Irama 212 juga masih memiliki minat baca yang rendah. Hal ini terjadi karena pemahaman pembaca belum terarah secara jelas akan manfaat yang diperoleh dengan membaca. Literasi merupakan salah satu motif yang dapat meningkatkan minat baca individu. Dengan adanya penguatan akan kegiatan literasi, individu akan merasa bahan bacaan yang dimilikinya menghasilkan manfaat baik bagi dirinya secara pribadi maupun orang lain. Selain itu, karya guna dari literasi yang dibuat oleh individu dapat menjadi nilai positif yang terus berkembang.

Penguatan akan pengelolaan dan kegiatan literasi di lingkungan masyarakat dapat dilakukan oleh pemerhati pendidikan, salah satunya Bimbingan dan Konseling. Dengan memanfaatkan berbagai layanan yang sesuai dengan kebutuhan, bimbingan dan konseling dapat membantu TBM Irama 212 dalam meningkatkan minat baca anggota (masyarakat sekitar) juga memberikan informasi yang sesuai untuk pengelolaan TBM Irama 212 secara efektif sehingga sejalan dengan Gerakan Literasi Nasional.

Literasi adalah poros pendidikan sepanjang hayat bagi masyarakat ${ }^{8}$. Dengan gerakan literasi masyarakat, yang sejalan dengan literasi sekolah dan keluarga diharapkan dapat lahir dan tumbuhnya simpul-simpul masyarakat yang literat. Kegiatan yang dikembangkan di gerakan literasi masyarakat adalah kegiatan yang mencakup enam literasi, yaitu :

\section{Literasi Bahasa}

Bahasa adalah dasar dari setiap kegiatan literasi. Literasi bahasa merupakan kemampuan untuk memahami, menggunakan dan merefleksikan tulisan dalam mencapai suatu tujuan, mengembangkan pengetahuan dan potensi untuk dapat berpartisipasi di masyarakat. Pemahaman literasi bahasa mencakup kemampuan membaca dan menulis; kualitas atau kemampuan melek huruf/aksara yang di

\footnotetext{
${ }^{8}$ Achmad Irwan Hamzani et al., "Peningkatan Kapasitas Sumber Daya Manusia Dengan Pemahaman Literasi Hukum,” Masyarakat Berdaya Dan Inovasi 1, no. 2 (2020): 56-61.
} 
dalamnya meliputi kemampuan membaca dan menulis; kemampuan dalam mengolah dan memahami informasi saat melakukan proses membaca dan menulis; dan kemampuan menuangkan gagasan dalam bentuk lisan dan tulisan ${ }^{9}$.

Kegiatan-kegiatan yang dapat dikembangkan dalam literasi bahasa adalah kegiatan sebagai berikut.

a. Membaca dan Bercerita

Kegiatan membaca bisa menjadi kegiatan yang menyenangkan jika dilakukan dengan bentuk yang beragam. Variasi kegiatan dalam membaca dan bercerita ${ }^{10}$, antara lain,

1) membaca senyap: membaca buku tanpa mengeluarkan suara. Kegiatan ini bisa dilakukan oleh setiap orang;

2) membaca nyaring (read aloud): membacakan buku dengan bersuara dan didengarkan oleh peserta lainnya; dan

3) membaca dan bercerita: memahami bahan bacaan kemudian menyampaikan kembali isi buku.

b. Kelompok Baca Berkala

Kelompok baca berkala adalah kegiatan untuk sama-sama membahas sebuah buku atau isu tertentu. Kegiatan ini untuk meningkatkan kemampuan masyarakat dalam membaca yang lebih komprehensif, meningkatkan kemampuan untuk menganalisis dan mengkritisi isu-isu tertentu yang sedang berkembang di masyarakat secara utuh 11 .

c. Penulisan Sejarah Daerah dan Potensi/Kearifan Lokal

Penulisan sejarah daerah atau potensi dan kearifan lokal sebuah daerah merupakan upaya bersama untuk memublikasikan dan melestarikan nilai-nilai dan sejarah suatu daerah agar tetap hidup di masyarakat. Publikasi dan penulisan bisa dilakukan di berbagai media, baik cetak maupun elektronik ${ }^{12}$.

\footnotetext{
${ }^{9}$ Redjeki Agoestyowati, "Branding Serial KKPK: Tinjauan Pada Minat Literasi Anak-Anak," Majalah Ilmiah Bijak 14, no. 1 (2017): 60-69.

${ }^{10}$ Andalusia Neneng Permatasari et al., "Literasi Dini Dengan Teknik Bercerita," FamilyEdu: Jurnal Pendidikan Kesejahteraan Keluarga 3, no. 1 (2017).

${ }^{11}$ Anjar Aprilia Kristanti, "Program Madrasah Membaca Sebagai Salah Satu Penanggulangan Tragedi Literasi Pada Generasi Z," Indonesian Journal of Islamic Teaching 2, no. 2 (2019): 1-15.

${ }^{12}$ Mustafa Mansur, "MEMBANGUN KARAKTER SISWA MELALUI KEARIFAN LOKAL (Suatu Tinjauan Di Halmahera Barat)," Jurnal Pusat Arkeologi Dan Kebudayaan (PUSAKA) 1, no. 1 (2020).
} 


\section{Literasi Numerasi}

Literasi berhitung merupakan kemampuan untuk merumuskan, menerapkan dan menafsirkan matematika dalam berbagai konteks, mencakup penalaran matematis dan menggunakan konsep matematika, prosedur, fakta dan alat-alat untuk menggambarkan, menjelaskan dan memprediksi fenomena ${ }^{13}$. Dalam konteks di masyarakat, literasi berhitung bertujuan untuk meningkatkan kemampuan dalam memahami peran dan kegunaan berhitung dalam aspek kehidupan sehari-hari, juga kemampuan untuk menyelesaikan masalah, menjelaskan proses dan menganalisis informasi yang berkaitan dengan numerasi. Ragam kegiatan yang dapat dikembangkan, antara lain, bermain dengan menggunakan hitung-hitungan dan angka. Seseorang disebut terliterasi numerasi jika (1) mengetahui dasar-dasar dari penjumlahan, pengurangan, perkalian dan pembagian; (2) dapat menggunakan konsep numerasi secara percaya diri dan efektif; dan (3) dapat memahami bagaimana mentransfer keterampilan yang dimiliki untuk memecahkan masalah ${ }^{14}$.

\section{Literasi Sains}

Literasi sains adalah kemampuan menggunakan pengetahuan sains dalam mengidentifikasi dan memperoleh pengetahuan baru, menggambarkan fenomena ilmiah dan menarik simpulan berdasarkan fakta ${ }^{15}$. Juga kemampuan untuk menggunakan pengetahuan sains, mengidentifikasi pertanyaan, dan menarik simpulan dalam rangka memahami, serta membuat keputusan yang berkenaan dengan alam ${ }^{16}$. Kegiatan-kegiatan yang dapat dikembangkan dalam literasi sains, antara lain, mengenal alam sekitar dan lingkungan, mengenal fenomena alam, belajar bersama dengan alat peraga sains, pengenalan hidup sehat. Seseorang disebut terliterasi sains jika memiliki kompetensi untuk (1) menjelaskan fenomena sains; (2) mengevaluasi dan mendesain pengetahuan dan keterampilan sains secara mandiri; dan (3) menginterpretasi data dan bukti sains ${ }^{17}$.

\footnotetext{
${ }^{13}$ Agus Maulana, "DESKRIPSI KEMAMPUAN LITERASI MATEMATIKA SISWA KELAS VIII-2 SMP NEGERI 15 KENDARI," Jurnal Penelitian Pendidikan Matematika 4, no. 2 (2017): 1-14.

${ }^{14}$ Abdul Halim Fathani, "Pengembangan Literasi Matematika Sekolah Dalam Perspektif Multiple Intelligences,” Edu Sains: Jurnal Pendidikan Sains Dan Matematika 4, no. 2 (2016).

${ }^{15}$ Nisa Wulandari, “Analisis Kemampuan Literasi Sains Pada Aspek Pengetahuan Dan Kompetensi Sains Siswa Smp Pada Materi Kalor,” Edusains 8, no. 1 (2016): 66-73.

${ }^{16}$ Yuyu Yuliati, "Literasi Sains Dalam Pembelajaran IPA,” Jurnal Cakrawala Pendas 3, no. 2 (2017).

${ }^{17}$ Wulandari, "Analisis Kemampuan Literasi Sains Pada Aspek Pengetahuan Dan Kompetensi Sains Siswa Smp Pada Materi Kalor."
} 


\section{Literasi Digital}

Literasi teknologi informasi dan komunikasi merupakan keterampilan berpikir kritis dan kreatif terhadap informasi dan komunikasi sebagai warga global dengan bertanggung jawab dan beretika dalam menggunakan perangkat teknologi informasi dan komunikasi ${ }^{18}$. Tujuannya adalah mengedukasi masyarakat dalam memanfaatkan teknologi dan komunikasi dengan menggunakan teknologi digital dan alat-alat komunikasi atau jaringan untuk menemukan, mengevaluasi, menggunakan, mengelola, dan membuat informasi secara bijak dan kreatif ${ }^{19}$. Fitur-fitur yang perlu dipahami mencakup dasar-dasar komputer, penggunaan internet dan programprogram produktif, keamanan dan kerahasiaan, dan gaya hidup digital. Kegiatankegiatan yang dapat dikembangkan, antara lain, adalah

a. mengenal dan belajar menggunakan perangkat komputer;

b. belajar menggunakan media sosial sebagai sarana publikasi kegiatan dan hal-hal yang kreatif;

c. mengikuti pelatihan jurnalistik menggunakan media teknologi komputer; dan

d. memanfaatkan teknologi untuk wirausaha ${ }^{20}$.

5. Literasi Finansial

Menurut Otoritas Jasa Keuangan (OJK), literasi finansial adalah rangkaian proses atau aktivitas untuk meningkatkan pengetahuan, keyakinan, dan keterampilan konsumen serta masyarakat luas sehingga mereka mampu mengelola keuangan dengan baik. Tujuan literasi finansial adalah mengedukasi masyarakat terkait dengan pengetahuan dasar tentang uang, pengelolaan dan pemanfaatan uang, serta organisasi manajemen keuangan dan investasi ${ }^{21}$.

Bentuk kegiatan yang dapat dikembangkan adalah mengenal jasa keuangan dan investasi, membangun koperasi bersama, mengenal transaksi keuangan elektronik. Rangkaian proses atau aktivitas dilakukan untuk meningkatkan pengetahuan,

\footnotetext{
${ }^{18}$ I Putu Gede Sutrisna, "GERAKAN LITERASI DIGITAL PADA MASA PANDEMI COVID-19," Stilistika: Jurnal Pendidikan Bahasa Dan Seni 8, no. 2 (2020): 269-83.

19 Sutrisna.

${ }^{20}$ Lutfiyah Nurul Wakhidah, Sunismi Sunismi, and Alifiani Alifiani, "Pengembangan Bahan Ajar Berbasis Literasi Digital Dan Kompetensi Abad XXI Pada Materi Barisan Kelas XI,” Jurnal Penelitian, Pendidikan, Dan Pembelajaran 15, no. 33 (2020).

${ }^{21}$ Irin Widyawati, "Faktor-Faktor Yang Mempengaruhi Literasi Finansial Mahasiswa Fakultas Ekonomi Dan Bisnis Universitas Brawijaya," Assets: Jurnal Akuntansi Dan Pendidikan 1, no. 1 (2012): 89-99.
} 
keyakinan, dan keterampilan konsumen dan masyarakat sehingga mereka mampu mengelola keuangan dengan baik.

Bagaimanapun, kemampuan diperoleh untuk memahami bagaimana uang berpengaruh di dunia. Seseorang melakukan pengaturan untuk menghasilkan uang, mengelola uang, menginvestasikan uang, dan menyumbangkan uang untuk menolong sesama menjadi penting dalam literasi finansial.

6. Literasi Budaya dan Kewarganegaraan

Literasi kebudayaan adalah pengetahuan tentang sejarah, kontribusi, dan perspektif dari kelompok budaya yang berbeda. Literasi kewarganegaraan merupakan pemahaman mengenai bentuk dan fungsi pemerintahan, kewarganegaraan, serta partisipasi sosial dan politik individu. Sasaran dari literasi budaya dan kewarganegaraan adalah mengedukasi masyarakat terkait sejarah dan perspektif budaya serta kewarganegaraan ${ }^{22}$. Bentuk kegiatan yang dapat dikembangkan adalah sebagai berikut.

a. Rembuk Budaya Lokal

Urun rembuk bersama komponen masyarakat untuk menghidupkan tradisi lokal yang dulu pernah ada di masyarakat untuk dikenalkan kembali kepada generasi penerus.

b. Gelar Budaya

Kegiatan pagelaran budaya yang menampilkan kembali kekayaan tradisi/budaya lokal melibatkan seluruh komponen masyarakat. Di beberapa daerah, pagelaran budaya bahkan dikembangkan menjadi potensi wisata.

\section{METODE PENELITIAN}

Penelitian ini dilakukan dengan pendekatan kualitatif. Jenis penelitiannya yaitu studi kasus. Penelitian dilakukan di Taman Baca Masyarakat Irama 212 Kota Depok. Data yang diperoleh adalah hasil: observasi, wawancara, dan dokumentasi. Subjek dalam penelitian ini adalah pengurus Taman Baca yang berkeinginan meningkatkan kualitas program taman bacanya ${ }^{23}$. Analisis data dalam penelitian ini menggunakan

\footnotetext{
${ }^{22}$ Wiwin Yulianingsih, Gunarti Dwi Lestari, and Rezka Arina Rahma, "PARENTING EDUCATION DALAM LITERASI BUDAYA DAN KEWARGAAN," in Prosiding Seminar Nasional \& Temu Kolegial Jurusan PLS Se-Indonesia, 2018, 55-58.

${ }^{23}$ Robert K Yin, "Case Study Methods.," 2012; Rizqa Sabrina, "Konseling Eksitensial Untuk Meningkatkan Kebermaknaan Hidup Pada Penderita Skizofrenia: Studi Kasus,” 2017.
} 
Model Miles dan Huberman ${ }^{24}$ terdiri dari tiga langkah meliputi reduksi data, penyajian data, dan penarikan kesimpulan.

\section{HASIL PENELITIAN DAN PEMBAHASAN}

Kegiatan pengabdian kepada masyarakat yang dilakukan pada pengurus dan anggota TBM Irama 212 dengan tema Gerakan Literasi Nasional pada Taman Baca Masyarakat memberikan pengalaman yang positif dengan bertambahnya wawasan, pengetahuan, keterampilan, nilai, dan sikap terhadap pengembangan dan peningkatan minat literasi pada masing-masing pihak. Adanya respon positif yang ditunjukkan dengan perbedaan pemahaman kondisi awal remaja dengan kondisi akhir pengurus TBM Irama 212 setelah diberikan layanan informasi dengan tema Strategi Pengembangan Gerakan Literasi Nasional di Taman Baca Masyarakat.Keberhasilan ini dapat ditunjukkan dengan hal sebagai berikut:

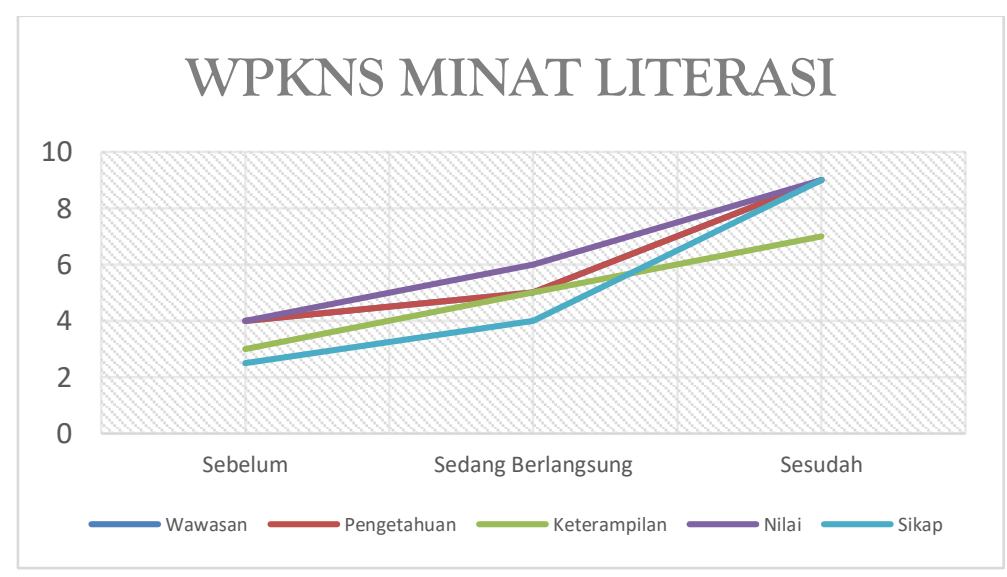

Grafik 1. Peningkatan WPKNS dalam Peningkatan Minat Literasi

\section{Peningkatan Wawasan dan Pengetahuan dalam Membangun Minat Literasi}

Pengurus TBM sebelumnya sudah memiliki program yang cukup bagus dari wawasan yang dimiliki. Namun informasi yang diberikan menambah wawasan pengurus menjadi lebih luas dan mendalam. Terlebih dalam hal literasi budaya dan kewarganegaraan yang belum pernah diterapkan. Sementara pada jenis literasi lainnya, para pengurus juga mengalami peningkatan wawasan seperti pada teknik literasi membaca dan literasi digital. Wawasan dan pengetahuan ini, peneliti

${ }^{24}$ Prof Sugiyono, "Metode Penelitian Kombinasi (Mixed Methods)," Bandung: Alfabeta, 2015. 
sampaikan berdasar panduan Gerakan Literasi Nasional yang disusun oleh lembaga Pemerintah yang sebelumnya belum dimiliki oleh para pengurus TBM 212.

\section{Peningkatan Keterampilan dalam Membangun Minat Literasi}

Berdasarkan wawasan dan pengetahuan yang telah diperoleh para pengurus TBM 212, mereka memiliki ide dan kemudian menambah keterampilan dalam menyusun program literasi pada Taman Baca Masyarakat yang dikelolanya.

\section{Peningkatan Nilai dalam Membangun Minat Literasi}

Nilai-nilai yang terkandung dalam peningkatan literasi juga semakin berkembang. Pengurus menjadi lebih merasa bertanggung jawab untuk mengembangkan potensi generasi di lingkungannya melalui gerakan literasi pada taman baca yang mereka kelola. Nilai budaya terkembang sehingga mendorong pengurus lebih giat melakukan literasi budaya.

\section{Peningkatan Sikap dalam Membangun Minat Literasi}

Wawasan, pengetahuan, keterampilan, dan nilai yang sudah dimiliki, mendorong pengurus TBM Irama 212 untuk menunjukkan sikap positif dan sistematis dalam mengembangkan kegiatan yang diprogramkan dengan penuh tanggung jawab. Pengurus mengembangkan ide-ide baru dalam menumbuhkembangkan minat literasi para anggotanya dengan lebih terstruktur dan menarik.

\section{PENUTUP}

Berdasarkan hasil yang telah dipaparkan melalui wawancara konseling, observasi konselor dan lembar evaluasi konseling, para pengurus TBM Irama 212 merasa antusias dalam mengembangkan program taman baca yang mereka kelola. Para pengurus bahkan sudah memiliki gambaran program pengembangan yang akan diselenggarakan. Maka dapat dikatakan bahwa penguatan minat literasi melalui layanan informasi pada Taman Baca Masyarakat berhasil. Dengan demikian, ini dapat menjadi rujukan bagi para konselor untuk dapat diterapkan pada kegiatan Gerakan Literasi nasional khususnya pada Taman Baca Masyarakat.

\section{DAFTAR RUJUKAN}

Afriani, Dian A. "Pelaksanaan Pendidikan Agama Islam Di Lingkungan Keluarga, Sekolah Dan Masyarakat.” Zirah 1, no. 1 (2019): 99-105. Agoestyowati, Redjeki. "Branding Serial KKPK: Tinjauan Pada Minat Literasi 
Anak-Anak." Majalah Ilmiah Bijak 14, no. 1 (2017): 60-69.

Fathani, Abdul Halim. "Pengembangan Literasi Matematika Sekolah Dalam

Perspektif Multiple Intelligences.” Edu Sains: Jurnal Pendidikan Sains Dan

Matematika 4, no. 2 (2016).

Hamzani, Achmad Irwan, Tiyas Vika Widyastuti, Sanusi Sanusi, Imam Asmarudin, Muhammad Wildan, and Erwin Aditya Pratama. "Peningkatan Kapasitas

Sumber Daya Manusia Dengan Pemahaman Literasi Hukum." Masyarakat

Berdaya Dan Inovasi 1, no. 2 (2020): 56-61.

Ihsan, Bisarul. "PERAN PEMBELAJARAN BUDAYA LOKAL DALAM PEMBENTUKAN KARAKTER SISWA MADRASAH IBTIDAIYAH (MI)." MIDA: Jurnal Pendidikan Dasar Islam 2, no. 2 (2019): 1-8.

Kristanti, Anjar Aprilia. "Program Madrasah Membaca Sebagai Salah Satu Penanggulangan Tragedi Literasi Pada Generasi Z." Indonesian Journal of Islamic Teaching 2, no. 2 (2019): 1-15.

Kurniawati, Etik. "MANAJEMEN LEMBAGA PENDIDIKAN ISLAM DALAM MENINGKATKAN PROFESIONALISME GURU DI SMP IT DARUSSALAM SRAGEN." Jurnal PROGRESS: Wahana Kreativitas Dan Intelektualitas 7, no. 1 (2019).

Mansur, Mustafa. "MEMBANGUN KARAKTER SISWA MELALUI KEARIFAN LOKAL (Suatu Tinjauan Di Halmahera Barat)." Jurnal Pusat Arkeologi Dan Kebudayaan (PUSAKA) 1, no. 1 (2020).

Maulana, Agus. "DESKRIPSI KEMAMPUAN LITERASI MATEMATIKA SISWA KELAS VIII-2 SMP NEGERI 15 KENDARI.” Jurnal Penelitian Pendidikan Matematika 4, no. 2 (2017): 1-14.

Permatasari, Andalusia Neneng, Dinar Nur Inten, Dewi Mulyani, and Nan Rahminawati. "Literasi Dini Dengan Teknik Bercerita." FamilyEdu: Jurnal Pendidikan Kesejahteraan Keluarga 3, no. 1 (2017).

Sabrina, Rizqa. "Konseling Eksitensial Untuk Meningkatkan Kebermaknaan Hidup Pada Penderita Skizofrenia: Studi Kasus," 2017.

Saihudin, H. Manajemen Sumber Daya Manusia. Uwais Inspirasi Indonesia, 2019.

Sugiyono, Prof. "Metode Penelitian Kombinasi (Mixed Methods)." Bandung: Alfabeta, 2015.

Suswandari, Meidawati. "Membangun Budaya Literasi Bagi Suplemen Pendidikan Di Indonesia." Jurnal Dikdas Bantara 1, no. 1 (2018).

Sutrisna, I Putu Gede. "GERAKAN LITERASI DIGITAL PADA MASA PANDEMI COVID-19.” Stilistika: Jurnal Pendidikan Bahasa Dan Seni 8, no. 2 (2020): 269-83.

Wakhidah, Lutfiyah Nurul, Sunismi Sunismi, and Alifiani Alifiani. "Pengembangan Bahan Ajar Berbasis Literasi Digital Dan Kompetensi Abad XXI Pada Materi Barisan Kelas XI.” Jurnal Penelitian, Pendidikan, Dan Pembelajaran 15, no. 33 (2020).

Widyawati, Irin. "Faktor-Faktor Yang Mempengaruhi Literasi Finansial Mahasiswa Fakultas Ekonomi Dan Bisnis Universitas Brawijaya." Assets: Jurnal Akuntansi Dan Pendidikan 1, no. 1 (2012): 89-99.

Wulandari, Nisa. "Analisis Kemampuan Literasi Sains Pada Aspek Pengetahuan Dan Kompetensi Sains Siswa Smp Pada Materi Kalor.” Edusains 8, no. 1 (2016): 66-73.

Yayuk, Erna, Kuncahyono Kuncahyono, and Arina Restian. "Pendampingan 
Rosyada: Islamic Guidance and Counseling

Vol 1. No. 12020

Gerakan Literasi Sains (GLS) Di SDN Girimoyo 2 Malang." Publikasi Pendidikan 8, no. 3 (2018): 172-78.

Yin, Robert K. "Case Study Methods.," 2012.

Yuberta, Kurnia Rahmi. "KEMAMPUAN LITERASI MATEMATIS SISWA DENGAN MENERAPKAN MODEL PEMBELAJARAN CREATIVE PROBLEM SOLVING (CPS).” Jurnal Saintika Unpam: Jurnal Sains Dan Matematika Unpam 3, no. 1 (2020): 68-80.

Yulianingsih, Wiwin, Gunarti Dwi Lestari, and Rezka Arina Rahma. "PARENTING EDUCATION DALAM LITERASI BUDAYA DAN KEWARGAAN." In Prosiding Seminar Nasional \& Temu Kolegial Jurusan PLS Se-Indonesia, 55-58, 2018.

Yuliati, Yuyu. "Literasi Sains Dalam Pembelajaran IPA.” Jurnal Cakrawala Pendas 3, no. 2 (2017). 